\title{
Determinants of participative budgeting and its implication on managerial performance
}

\author{
Yunika Murdayantia ${ }^{\text {* }}$, Susi Indriani ${ }^{a}$ and Widad Umaimah ${ }^{a}$
}

\begin{tabular}{l}
${ }^{a}$ Faculty of Economics, Universitas \\
\hline C H R O N I C L E \\
\hline Article history: \\
Received: June 29, 2020 \\
Received in revised format: \\
July 30 2020 \\
Accepted: August 25, 2020 \\
Available online: \\
August 25, 2020 \\
\hline Keywords: \\
Organization Commitment \\
Procedural Fairness \\
Participative Budgeting \\
Managerial Performance \\
\end{tabular}
\section{A B S T R A C T}

\begin{abstract}
The purpose of this study is to examine the effect of organizational commitment and procedural fairness against participative budgeting, organization commitment and procedural fairness against managerial performance, and participative budgeting on managerial performance in Jakarta Capital City Government. The populations are structural agencies of the regional work unit in Jakarta, with 100 structural agencies of the regional work unit in Jakarta as the sample. This research uses primary data collected by questionnaires. The analysis data method uses path analysis with Smart PLS to test the direct effect and indirect effect between variables. The results of this study present that organizational commitment did not affect participatory budgeting as well as managerial performance, procedural justice had a positive and significant effect on participatory budgeting as well as on managerial performance and participatory budgeting had a positive and significant effect directly or indirectly on managerial performance.
\end{abstract}

(C) 2021 by the authors; licensee Growing Science, Canada

\section{Introduction}

Financial management and governance in Indonesia from time to time have undergone dynamic changes following the times. The financial management carried out by the government is sourced from state revenue and state expenditure which can affect the operation of the price mechanism and good arrangement in the state budget. The state budget is very important because the plan is a political decision between the government and the legislative body, namely the House of Representatives, so what is included in the revenue budget, expenditure budget and financing budget are the results of calculations that constitute political policies concerning finance state. The state budget can also be seen as a means of controlling state finances since they are the limits set in the legislation. The budget as an instrument of economic policy serves to realize economic growth and stability as well as an even distribution of opinions to achieve the objectives of the state (Halim, 2016). Regional Budget Revenues and Expenditures (APBD) is the main policy instruments for regional governments. As a policy instrument, the regional budget occupies a central position in efforts to develop the capacity and effectiveness of local governments. The regional budget aims as a tool in determining income and expenditure, helping development planning decisions, spending authorization, developing sources of standard measures for performance appraisal, also a tool to mobilize employees and to coordinate for all activities in various work units (Ulupui, 2005). The need for a decision-making process involves participation at every level in government management. Participation from subordinates in the preparation of the budget can provide an opportunity to enter local information. Subordinates can communicate or disclose some personal information that can be included in the budget used as a basis for performance evaluation of subordinates participate in the budgeting process. Participatory budgeting will improve managerial performance in providing better public services, or in other words, budgetary participation will increase the responsibilities and performance of lower and middle-level managers. Managers can convey their creative ideas to top managers,

* Corresponding author

E-mail address: yunika_murdayanti@unj.ac.id (Y.Murdayanti) 
and those ideas have the goal of achieving company goals. From the participation of middle and lower-level managers in determining the budget, a more realistic decision will be obtained so that greater corporate goals are created (Nor in Octavia, 2009 in Wuner and Subardjo, 2016). The increase of organizational commitment will also increase high performance (Sumarno, 2005 in Wulandari and Riharjo, 2016). Organizational commitment is needed as an indicator of employee performance. Employees with higher commitment can be expected to show optimal performance. A person who joins an organization in a company or government agency is required to commit themselves. Procedural justice also has a role in the budgeting process and managerial performance. Libby (1999) in Rachman (2014) recognizes an organization works with limited resources cannot fulfill all requests related to budgeting. Therefore, there must be a fair procedure to distribute limited resources. Lau and Lim (2007), Yucel and Gunluk (2007) in Rachman (2014) explain that procedural justice is a subordinate's perception of the fairness of the process used by the leader (superior) to evaluate the performance of subordinates, communicate feedback on the performance achieved, and determine appreciation for subordinates. The effect of procedural justice on participatory budgeting can be seen from the initiatives increase and information sharing between superiors and subordinates (Wang \& Nayir, 2010 in Rachman 2014; Al-Nawafah \& Almarshad, 2020).

Based on this background, the purpose of this study proves the effect of organizational commitment and procedural fairness on participatory budgeting and its implications on managerial performance with objects in this study that have not been examined in previous relevant studies of the DKI Jakarta Provincial Government SKPD as budget users.

\section{Literature Review}

\subsection{Participatory Budgeting}

Brownell's Participatory Budgeting (1982) in Wulandari (2016) describes participatory budgeting as a process that involves individuals directly in it and has an influence on the preparation of budget goals whose achievements will be assessed and likely to be valued based on achieving their budget goals. Broad participation is an organizational process, members of the organization are involved and have influence in an act of decisions that have an interest in them (Rachman, 2014).

\subsection{Managerial Performance}

Managerial performance is the assessment of the results of the implementation of the manager's role carried out in the organization. Managerial performance measurement is based on the implementation of management functions by measuring the extent to which managers can carry out these functions consist of planning, investigation, coordination, evaluation, supervision, staff selection, negotiation, and representation.

\subsection{Organizational Commitment}

Organizational commitment is an important behavioral dimension that can be used to assess the tendency of employees to stay as members of the organization (Mowday, 1982 in Rachman, 2014). Whereas Luthans (2006) in Wulandari (2016) provides the opinion that organizational commitment is most often defined as a strong desire to remain as a member of a particular organization, a desire to strive according to organizational desires, certain beliefs, acceptance of values and organizational goals.

\subsection{Procedural Justice}

Procedural justice is a belief about fair performance evaluation can also be based on the procedure by which evaluation is determined (Greenberg, 1986 in Khairani, 2015). Procedural justice as perceived justice related to the way used to determine the amount of compensation, or in other words, procedural justice is more seen from the suitability of the procedure in making certain decisions (Indrayani \& Wahyudi, 2020).

\subsection{Hypothesis Development}

\section{The Effect of Organizational Commitment on Participatory Budgeting}

Organizational commitment encourages managers to participate in budgeting. Supriyono (2006) in Rachman (2014) explains that organizational commitment encourages participation in budgeting, the participation of lower-level managers to propose to top-level managers is the best effort of managers who benefit the organization in achieving the goals of the organization which they lead. The existence of organizational commitment makes the individual will do the best for the organization. Organizational commitment approaches to support the findings that draw attention to the relationship between organizational commitment and individual psychological processes, organizational commitment has a psychological dimension and the relationship arises in the 
form of behavior as a result of work relationships with the organization and ensures individuals make informed decisions aims to maintain the continuation of the organization. Employees who positively develop organizational commitment in an organizational environment provide opportunities to participate in decision making. Rachman (2014) stated that organizational commitment influences participatory budgeting. The higher organizational commitment can increase participatory budgeting in the regional work unit. The manager's strong belief in the goals and values of the organization encourages managers to participate in budgeting.

H1: Organizational commitment has a positive effect on participatory budgeting.

\section{The Effect of Procedural Justice on Participatory Budgeting}

Procedural justice is related to the influence of fair decision-making procedures on the attitudes and behavior of the people involved in and influenced by their decisions (Maiga and Jacobs, 2007 in Rachman 2014). In other words, procedural justice is recognized as having a positive benefit on the participation of employees in decision making. Wang and Nayir (2010) in Rachman (2014) stated that the influence of procedural justice on participatory budgeting can be seen from the increasing initiative and sharing of information between superiors and subordinates. Procedural justice is a side of justice in budgeting that pays attention to aspects of the procedures used in distributing the budget (Rachman, 2014). The results of other studies conducted by Rachman showed that regional work unit officials understood the existence of procedures in preparing the budget and the distribution of the budget for each area.

$\mathbf{H}_{2}$ : Procedural justice has a positive effect on participatory budgeting.

\section{The Effect of Organizational Commitment on Managerial Performance}

Wuner and Subardjo (2016) in the influence of organizational commitment on managerial performance defines organizational commitment as a combination of attitudes and behavior. Organizational commitment is formed with employee commitment. Employees who are committed to their organization will show positive attitudes and behavior. A manager will need high loyalty to his organization to keep trying to improve performance and have a certain confidence to realize organizational goals. Other research conducted by Rachman (2014) also showed a relationship between organizational commitment and managerial performance.

H3: Organizational commitment has a positive effect on the managerial performance of local governments.

\section{The effect of Procedural Fairness on Managerial Performance}

Procedural justice is an important factor that can improve the results of managerial performance, this is based on research conducted by Tanjung (2016) which shows that procedural justice has a positive effect on the managerial performance of the public sector. Other research conducted by Rachman (2014) also shows the same thing.

H4: Procedural justice has a positive effect on the managerial performance of local governments.

\section{The effects of Participatory Budgeting on Managerial Performance}

Participatory budgeting is expected to increase managerial performance, where when a goal is designed and participative approved, subordinates will internalize the goals set by having a personal sense of responsibility to achieve them because they are involved in budgeting. Budgeting participation can be assessed as a managerial approach that can improve the performance of each member of the organization as an individual because with the participation in budgeting is expected that each individual can improve their performance by predetermined targets (Nazaruddin and Setyawan, 2012). Other research on the effect of participatory budgeting on performance which results in the existence of influence was suggested by Wuner and Subardjo (2016), Khairani (2015), Sukandani and Istikhoroh (2016), and Mah'd et al. (2013).

Hs: Participatory budgeting has a positive effect on the managerial performance of local governments.

\section{Research Method}

The method used in this study is a quantitative method by testing the effect of organizational commitment and procedural fairness on participatory budgeting and its implications for managerial performance. The population in this study were structural officials involved in the preparation of the budget in the DKI Jakarta Provincial Government in 2018. A total of 5.066 officials held positions as heads of the regional work unit, heads of fields, heads of subdivisions, section heads, and other officials spread over 42 regional work unit in DKI Jakarta Provincial Government consisting of 2 secretariats, 1 inspectorate, 10 agencies, 22 offices, 1 unit, 5 administrative cities, and 1 district. The sample in this study was selected using the Slovin formula. The number of respondents in this study was 100 respondents, with the calculation of the Slovin formula as $n=\frac{\mathrm{N}}{1+\mathrm{N}(e)^{2}}=\frac{5066}{1+5066(10 \%)^{2}}=$ 
98,064; adjusted to be 100 . The sampling technique used in this study is multistage sampling, which is a sample selection technique that is carried out in stages. The use of this technique is due to the large and widespread population in several administrative cities of DKI Jakarta and the length of the research bureaucratic process in the Provincial Government of DKI Jakarta.The method used in this study is quantitative and to analyze the data used Path Analysis with the help of smart Partial Least Square software. Data collection was carried out using the direct distribution method, which is to go to the respondents directly to submit or collect the questionnaire. The questionnaire technique will be distributed to the research object, namely the DKI Jakarta Provincial Government and filled by top-level managers, middle-level managers, and lower-level managers in the DKI Jakarta Provincial Government who participate in preparing the budget.

\section{Results}

Structural model testing in the path analysis in this study is used to measure the correlation between the related variables. The path analysis used is the trimming model path analysis. The structural model in this study is restated as shown in the following figure.

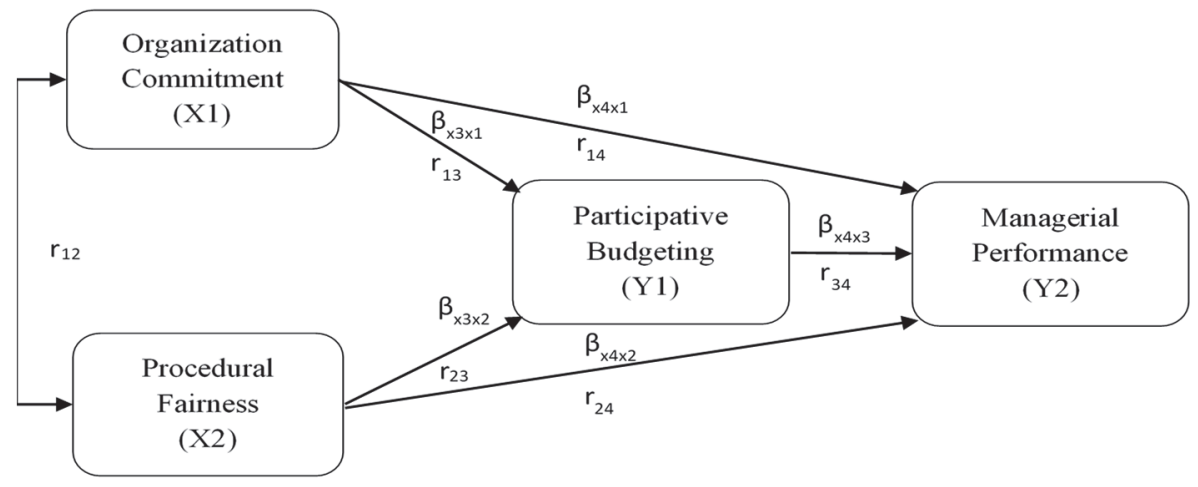

Fig. 1. Relationship Between Variables

In the path diagram above, five path coefficients can be obtained, namely $\beta 31, \beta 32, \beta 41, \beta 41$ and $\beta 43$ and six correlation coefficients namely r12, r13, r14, r23, r24 and r34. This structural model consists of two sub-structures, namely sub-structure1 and sub-structure-2. Furthermore, by using further calculations by the steps in the path analysis, the path coefficient values are calculated and tested for significance using t-statistics. T-Statistics Test or significance test is used to find out how much influence the independent variable has on the dependent variable.

Table 1

T-Statistics Test Results

\begin{tabular}{|c|c|c|c|c|c|}
\hline & Path coefficient & Sample Mean (M) & Standard Deviation & T Statistics & P Values \\
\hline $\mathrm{KO} \rightarrow \mathrm{PP}$ & 0.121 & 0.131 & 0.107 & 1.131 & 0.258 \\
\hline $\mathrm{KO} \rightarrow \mathrm{KM}$ & 0.172 & 0.18 & 0.123 & 1.403 & 0.161 \\
\hline $\mathbf{K P} \rightarrow \mathbf{P P}$ & 0.291 & 0.292 & 0.107 & 2.735 & 0.006 \\
\hline $\mathbf{K P} \rightarrow \mathbf{K M}$ & 0.314 & 0.319 & 0.129 & 2.443 & 0.015 \\
\hline $\mathbf{P P} \rightarrow \mathbf{K M}$ & 0.308 & 0.311 & 0.095 & 3.229 & 0.001 \\
\hline
\end{tabular}

\section{Calculation of Path Coefficient in Sub-Structure 1}

Causal relationships between variables in sub-structure-1 consist of one endogenous variable (Y1) and two exogenous variables (X1 and X2).

Table 2

Calculation Results for the Test for the Path Coefficient Model 1 Sub-Structure-1

\begin{tabular}{|c|c|c|c|c|}
\hline Path & Path coefficient & t statistic & $\begin{array}{c}\text { t table } \\
(\alpha=0.05)\end{array}$ & Information \\
\hline$\beta_{\times 3 \times 1}$ & 0.121 & 1.131 & 1.984 & Not significant \\
\hline$\beta_{\times 3 \times 2}$ & 0.291 & 2.735 & 1.984 & significant \\
\hline
\end{tabular}

Based on the path analysis in model 1 sub-structure- $1(\mathrm{X} 1$ and $\mathrm{X} 2$ to $\mathrm{Y} 1)$, values are obtained : $\beta_{\mathrm{x} 3 \mathrm{x} 1}=\mathrm{Beta}=0,121[\mathrm{t}=1,131]$

$$
\beta_{\mathrm{x} 3 \times 2}=\text { Beta }=0,291[\mathrm{t}=2,735]
$$


The analysis proves that there is no significant path coefficient between organizational commitment (X1) and participatory budgeting (Y1), then the model in the picture above needs to be improved by the trimming method. The improvement that needs to be done is not to include the organizational commitment variable (X1) in the next calculation. The results of the recalculation are shown in the following table.

Table 3

Calculation Results and Testing of the Path Coefficient Model 2 Sub-Structure-1

\begin{tabular}{ccccccc} 
Path & Path coefficient & Sample Mean & $\begin{array}{c}\text { Standard } \\
\text { Deviation/on }\end{array}$ & T Statistics & P Values & Information \\
\hline $\boldsymbol{\beta}_{\mathbf{x} 3 \mathbf{2} 2}$ & 0.361 & 0.373 & 0.079 & 4.557 & 0 & Significant \\
\hline
\end{tabular}

Based on the path analysis in model 2 sub-structure-1 (X2 to Y1) obtained values:

$$
\beta_{\times 3 \times 2}=\text { Beta }=0,361[\mathrm{t}=4,557]
$$

The magnitude of the determinant coefficient (contribution) $\mathrm{X} 2$ to $\mathrm{Y} 1$ of (R square) $=0.130$, which means that a $13 \%$ variation in participatory budgeting (Y1) can be explained by variations in procedural fairness (X2). The residual coefficient for $(\beta \times 3) \varepsilon 1$ $=\sqrt{ }((1-0,130))=0.933$ is the influence of other variables outside of X2. Thus the structural equation for sub-structure-1 is Y1 $=0.361 \mathrm{X} 2+0.933 \varepsilon 1$. As for the path diagram sub-structure-1 underwent a change, which is to be like in the following figure:

\section{Calculation of Path Coefficient in Sub-Structure 2}

Causal relationships between variables in sub-structure- 2 consist of one endogenous variable (Y2) and three exogenous variables $(\mathrm{X} 1, \mathrm{X} 2$, and $\mathrm{Y} 1)$. The structural equation for sub-structure-2 is $\mathrm{Y} 2=\beta \times 4 \times 1 \mathrm{X} 1+\beta \times 4 \times 2 \times 2+\beta \times 4 \times 3 \mathrm{Y} 1+\varepsilon 2$.

Table 4

Results of Calculation and Testing of the Path Coefficient Model 1 Sub-Structure-2

\begin{tabular}{lcccl}
\hline Path & Path coefficient & t statistic & t table & Information \\
\cline { 4 - 5 } & & & $(\alpha=0.05)$ & \\
\hline $\boldsymbol{\beta}_{\mathbf{x} 4 \mathbf{x}}$ & 0.172 & 1.403 & 1.984 & Not significant \\
$\boldsymbol{\beta}_{\mathbf{x} 4 \mathbf{2} 2}$ & 0.314 & 2.443 & 1.984 & Significant \\
$\boldsymbol{\beta}_{\mathbf{x} 4 \mathbf{x} 3}$ & 0.308 & 3.229 & 1.984 & Significant \\
\hline
\end{tabular}

Based on the path analysis in model 1 sub-structure-2 (X1, X2 and Y1 to Y2) values were obtained:

$$
\begin{aligned}
& \beta_{\times 4 \times 1}=\text { Beta }=0,172[\mathrm{t}=1,403] \\
& \beta_{\times 4 \times 2}=\text { Beta }=0,314[\mathrm{t}=2,443] \\
& \beta_{\times 4 \times 3}=\text { Beta }=0,308[\mathrm{t}=3,229]
\end{aligned}
$$

The analysis proves that there is no significant path coefficient between organizational commitment (X1) and managerial performance (Y2), so the model in the picture above needs to be improved by the trimming method. The improvement that needs to be done is not to include the organizational commitment variable (X1) in the next calculation. The results of the recalculation are shown in the following table.

\section{Table 5}

Results of Calculation and Testing of Path Coefficients Model 2 Sub-Structure-2

\begin{tabular}{ccccccc}
\hline Path & Path coefficient & Sample Mean & Standard Deviation & T Statistics & P Values & Information \\
\hline $\boldsymbol{\beta}_{\mathbf{x} \times \mathbf{2}}$ & 0.413 & 0.424 & 0.095 & 4.323 & 0 & Significant \\
$\boldsymbol{\beta}_{\mathbf{\times} 4 \times 3}$ & 0.324 & 0.333 & 0.095 & 3.4 & 0.001 & Significant \\
\hline
\end{tabular}

Based on the path analysis in model 2 sub-structure-2 (X2 and Y1 to Y2), the value is obtained:

$$
\begin{aligned}
& \beta_{\mathrm{x} 4 \times 2}=\text { Beta }=0,413[\mathrm{t}=4,323] \\
& \beta_{\mathrm{x} 4 \times 3}=\text { Beta }=0,324[\mathrm{t}=3,400]
\end{aligned}
$$

The magnitude of the determinant coefficient (contribution) $\mathrm{X} 2$ and $\mathrm{Y} 1$ to $\mathrm{Y} 2$ of (R square) $=0.372$, which means that $37.2 \%$ of the variation in managerial performance (Y2) can be explained by variations in procedural fairness (X2) and participatory budgeting (Y1). The residual coefficient for $(\beta \times 4) \varepsilon 2=\sqrt{ }((1-0,372))=0.792$, is the influence of other variables outside of X2 and $\mathrm{Y} 1$. Thus, the structural equation for sub-structures-2 is $Y_{2}=\mathbf{0 , 4 1 3 X 2}+\mathbf{0 , 3 2 4 Y} 1+\mathbf{0 , 7 9 2} \varepsilon_{2}$. 
The results of the path coefficients in sub-structure-1 and sub-structure-2 turn into structural equations as follows:

$\mathrm{Y}_{1}=0,361 \mathrm{X}_{2}+0,933 \varepsilon_{1}$ dan $\mathrm{R}^{2} \times 3 \times 2=0,130$

$\mathrm{Y}_{2}=0,413 \mathrm{X}_{2}+0,324 \mathrm{Y}_{1}+0,792 \varepsilon_{2}$ dan $\mathrm{R}_{\mathrm{x} 4 \times 3 \times 2}=0,372$

\section{Calculation of Direct and Indirect Effects between Variables}

Direct and indirect effects between variables on sub-structure-1

In sub-structure-1 there are two exogenous variables (X1 and X2) and one endogenous variable (Y1). Based on the results of calculations and testing of path coefficients, the magnitude of the direct and indirect effects of each exogenous variable can be interpreted towards endogenous variables.

Table 6

Effect of Exogenous Variables on Endogenous Sub-Structure-1

\begin{tabular}{lcccc}
\multicolumn{1}{c}{ Variable } & Direct Effect on & \multicolumn{2}{c}{ Indirect Effect Through } & \multicolumn{2}{c}{ Total Effect } \\
\cline { 3 - 5 } & Y1 & X1 & X2 \\
\hline Organizational Commitment (X1) & $0 \%$ & - & $19.927 \%$ & $19.927 \%$ \\
Procedural Justice (X2) & $13.032 \%$ & $0 \%$ & - & $13.032 \%$ \\
\hline
\end{tabular}

In the table above, it can be seen that organizational commitment (X1) directly influences participatory budgeting (Y1) by $0 \%$ and an indirect effect through procedural justice (X2) of $0.552 \times 0.361 \times 100 \%=19.927 \%$. Thus the total effect of organizational commitment (X1) on participatory budgeting (Y1) is $16.06 \%$. Procedural justice (X2) directly affects participatory budgeting (Y1): $0.361 \times 0.361 \times 100 \%=13.032 \%$ and an indirect effect through organizational commitment (X1) is $0 \%$ because organizational commitment does not have a direct influence on participatory budgeting. Thus the total effect of procedural fairness (X2) on participatory budgeting (Y1) was 13,032\%.

Direct and indirect effects between variables on sub-structure-2

I

n sub-structure-2 there are three exogenous variables (X1, X2, and Y1) and one endogenous variable (Y2). Based on the results of calculations and testing of path coefficients, the magnitude of the direct and indirect effects of each exogenous variable can be interpreted towards endogenous variables.

\section{Table 7}

Effect of Exogenous Variables on Endogenous Sub-Structure-2

\begin{tabular}{|c|c|c|c|c|c|}
\hline \multirow[t]{2}{*}{ Variable } & \multirow[t]{2}{*}{ Direct Effect on Y2 } & \multicolumn{3}{|c|}{ Indirect Effect Through } & \multirow[t]{2}{*}{ Total Effect } \\
\hline & & $\mathrm{X} 1$ & $\mathrm{X} 2$ & Y1 & \\
\hline Organizational Commitment (X1) & $0 \%$ & - & $22.80 \%$ & $6.46 \%$ & $29.25 \%$ \\
\hline Procedural Justice (X2) & $17.06 \%$ & $0 \%$ & - & $11.70 \%$ & $28.75 \%$ \\
\hline Participatory Budgeting (Y1) & $10.50 \%$ & - & - & - & $10.50 \%$ \\
\hline
\end{tabular}

In the table above, it can be seen that organizational commitment (X1) directly influences managerial performance (Y2) by $0 \%$, indirect effect through procedural justice (X2) in $0.552 \times 0.413 \times 100 \%=22.798 \%$ and indirect effect through budgeting participatory (Y1) amounting to $0.552 \times 0.361 \times 0.324 \times 100 \%=6.456 \%$. Thus, the total effect of organizational commitment (X1) on managerial performance (Y1) was 29.254\%. Procedural justice (X2) directly influences managerial performance (Y2) of: $0.413 \times 0.413 \times 100 \%=17.057 \%$, indirect effect through organizational commitment $(\mathrm{X} 1)$ is $0 \%$ because organizational commitment does not have a direct influence on managerial performance and has an effect indirectly through participatory budgeting (Y1) of: $0.361 \times 0.324 \times 100 \%=11.696 \%$. Thus, the total effect of procedural fairness $(\mathrm{X} 2)$ on managerial performance (Y2) was $28.753 \%$. While participatory budgeting (Y1) directly affects managerial performance (Y2) of: $0.324 \mathrm{x}$ $0.324 \times 100 \%=10.498 \%$.

\section{Discussion}

Organizational commitment has a positive effect on participatory budgeting

The results of testing the first hypothesis are known that organizational commitment does not directly influence participatory budgeting. This hypothesis is not in line with the results of research conducted by Rachman (2014) which stated that 
organizational commitment has a positive effect on participatory budgeting. Based on the results of the questionnaire, it shows that the structural officials of the DKI Jakarta Provincial Government are very committed to the organization where they work. This indicates that the committee held by the structural officials of the DKI Jakarta Provincial Government has nothing to do with the level of participatory budgeting in the DKI Jakarta.

\section{Procedural justice has a positive effect on participatory budgeting}

The results of testing the second hypothesis are accepted, so it can be said procedural justice has a positive and significant effect directly on participatory budgeting. The structural officials of the DKI Jakarta Provincial Government have understood the procedures in preparing the budget. So this research shows that procedural justice has a benefit to the participatory undertaken by structural officials of the DKI Jakarta Provincial. The higher procedural justice will increase regional work unit participatory budgeting. The results of this hypothesis are in line with the results of research conducted by Rachman (2014).

\section{Organizational commitment has a positive effect on managerial performance}

The results of testing the third hypothesis are denied, so it can be said that organizational commitment does not directly affect managerial performance. This hypothesis is not in line with the results of research conducted by Rachman (2014) which stated that organizational commitment has a positive effect on managerial performance. In other words, structural officials of the DKI Jakarta Provincial Government have high commitment to the organization, but that commitment does not produce a relationship to managerial performance.

\section{Procedural justice has a positive effect on managerial performance}

The fourth hypothesis testing results are received, so it can be said that procedural justice has a positive and significant effect directly on managerial performance. The higher the level of procedural justice of structural officials of the DKI Jakarta Provincial Government, the higher the managerial performance produced. This is in line with the results of research conducted by previous researchers such as Rachman (2014) and Tanjung (2016). This relationship is consistent with the theory of justice described by Pareke (2014), which referred to employee perceptions of fairness and the balance between the inputs they provide to the organization and the organizational outcomes they receive, as well as employee perceptions about the fairness of the processes used to distribute organizational outcomes.

\section{Participatory budgeting has a positive effect on managerial performance}

The fifth hypothesis testing results are received, so it can be said participatory budgeting has a positive and significant effect directly on managerial performance. These results indicate that high participation in the DKI Jakarta Provincial Government in the budget preparation process will improve the managerial performance of the DKI Jakarta Provincial Government. This result is in line with the results of research conducted by previous researchers such as Rachman (2014), Wuner and Subardjo (2016), Khairani (2015), Sukandani and Istikhoroh (2016), and Mah'd et al. (2013) which stated that participatory budgeting significantly influences managerial performance.

\section{Conclusion}

Organizational commitment does not affect participatory budgeting as well as managerial performance. The highest commitment of the structural officials to their place of work explained that there is a connection with the organization and the objectives to be achieved, hoped to maintain its membership in the place of work. As a government employee, it is only natural that structural officials of the DKI Jakarta Provincial Government have a high commitment to the organization where they work. Procedural justice has a positive and significant effect on participatory budgeting as well as on managerial performance. Procedural justice perceived by government employees as measured by the extent to which formal procedures are applied in decision making will make participation in budgeting and managerial performance better. With the outcome received well by government employees in the form of fairness in procedural decision-making, it should be that input is given by government employees to organizations in the form of participation in budgeting and good performance of their regional work unit. Participatory budgeting has a positive and significant effect directly or indirectly on managerial performance. The participation of lower-level managers up to the top level in the budget preparation process will make the managerial performance better. This is because the top-level managers in the regional work unit always involved lower-level managers to take part in the preparation of the regional work unit budget so that the lower-level managers feel proud and responsible for the budget they make. It is hoped that further researchers can expand and enlarge the research sample so that the data obtained can better represent the overall object of the study. Also, it is expected that all structural officials of the DKI Jakarta Provincial Government can work together in the process of preparing the budget up to the implementation of the budget and be accountable to the public about the work programs implemented and to produce a good performance on the DKI Jakarta Provincial Government. 


\section{References}

Al-Nawafah, S., \& Almarshad, M. (2020). The role of decentralization for balancing employee performance in governmental universities in Jordan. Management Science Letters, 10(14), 3217-3224.

Halim, Abdul. (2016). Public Sector Financial Management. Jakarta: Salemba Empat.

Indrayani, I., \& Wahyudi, D. (2020). Environmental management performance and the role of human resources management: Empirical study in quaternary economic sector. Management Science Letters, 10(16), 3967-3974.

Khairani, U. R. (2015). Effect of budget participation on managerial performance with distributive justice, procedural justice, commitment of budget purposes, and job relevant information as intervening variables. Jom FEKON, 2(2), 1-15

Mah'd, O., Al-Khadash, H., Idris, M., \& Ramadan, A. (2013). The impact of budgetary participation on managerial performance: Evidence from Jordanian university executives. Journal of Applied Finance \& Banking, 3(3), 133-156.

Pareke, F.J. (2004). Relationship of justice and satisfaction with moving desires: The role of organizational commitment as a mediating variable. Journal of Business Strategy, 2(9), 157-178.

Rachman, A. A. (2014). Effect of procedural justice on participatory budgeting through organizational commitment. Journal of Economics and Business, 17(3), 55-78

Sukandani, Y., \& Istikhoroh, S. (2016). Participatory budgeting role in improving the performance of managerial head of the East Java department. Review of European Studies, 8(4), 1918-7181

Tanjung, A. H. (2016). Regional Government Accounting Concepts and Applications According to Government Accounting Standards. Bandung: Alfabeta.

Ulupui, I.G.K. (2005). The influence of budget participation, distributive justice perception, procedural justice, and goal commitment on service performance. KINERJA, 9(2), 98-112.

Wulandari, D. E., \& Riharjo, I. B. (2016). Effects of participatory budgeting on managerial performance with organizational commitment and leadership styles. Journal of Accounting and Research, 5(4), 1-15

Wuner, D. R., \& Subardjo A. (2016). Budgetary participatory effects, organizational commitment to managerial performance of PT Jasa Marga Tbk. Journal of Accounting and Research, 5(9), 1-20

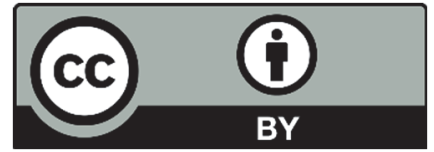

(C) 2020 by the authors; licensee Growing Science, Canada. This is an open access article distributed under the terms and conditions of the Creative Commons Attribution (CC-BY) license (http://creativecommons.org/licenses/by/4.0/). 